\title{
Alteration of Time Limits of Performance of Tax Liability in the Russian Tax and Customs Law
}

\section{$\Omega$ Aleksandr Kozyrin}

Professor, Department of Public Law, Law Faculty, National Research University Higher School of Economics, Doctor of Juridical Sciences. Address: 20 Myasnitskaya Str., Moscow 101000, Russia. E-mail: kozyrine@mail.ru

\section{凡目 Aleksandr Yalbulganov}

Professor, Department of Public Law, National Research University Higher School of Economics, Doctor of Juridical Sciences. Address: 20 Myasnitskaya Str., Moscow 101000, Russia. E-mail: yalbulganov@hse.ru

\section{瞷目 Abstract}

The article analyzes one of the central institutions of Russian tax law - alteration of the time limits for the payment of taxes. The right of the taxpayer to alter the execution of tax obligations, on one hand, demonstrates the desire of the legislator to ensure a balance of public and private interests in the implementation of tax regulation, and on the other hand, must guarantee the full implementation of the fiscal function of tax law. The fulfillment of the constitutional obligation to pay the established-by-law taxes involves the payment of taxes not only in full, but also on time. Alteration of the time limits doesn't cancel the existing tax obligation and doesn't create a new tax obligation. Having exercised the right to alter the time limit for fulfilling tax obligations, the taxpayer is able to pay tax at a later date than established by the legislation on taxes and fees, and at the same time not be held liable for violation of tax legislation. In order to maintain a balance of public and private interests in the tax sphere, a taxpayer's right to alter the time limits for the payment of taxes is compensated by his obligation to pay in established cases a percentage that compensates for the damage caused to the fiscal interests of the state and municipalities in the exercise of this right. The article analyzes the general procedure for exercising the taxpayer's right to alter the tax payment time limit established in the Tax Code of the Russian Federation (Chapter 9) and the acts of the Federal Tax Service adopted in accordance with it. Special cases of the realization of this right are also considered: when paying indirect taxes on goods imported into the territory of the customs union (in this case, the relevant norms of customs legislation are applied) and when altering the terms of payment of taxes credited to regional and local budgets (in this case, normative legal acts of constituent entities of the Russian Federation and municipalities). The article presents main forms of exercising the taxpayer's right to alter the terms of tax payment (deferral, installment plan and investment tax credit) and tax and customs authorities with the authority to make appropriate decisions. Particular attention is paid to the issues of protecting the fiscal interests of the state in case of termination of legal relations of altering the terms of payment of taxes (for example, protecting fiscal interests in case of early termination of the investment tax credit agreement). 


\section{0-1目 Keywords}

fiscal law, tax legislation, customs legislation, tax liability, alteration of the time limits of performance of tax liability, deferral of tax payment, installment, investment tax credit.

Acknowledgments: The article is fulfilled within framework of Academic Fund Program at the National Research University Higher School of Economics (HSE University) in 2019-2020 (grant N 19-01-036) and within framework of Russian Academic Excellence Project "5-100".

For citation: Kozyrin A.N., Yalbulganov A.A. (2019) Alteration of Time Limits of Performance of Tax Liability in the Russian Tax and Customs Law. Pravo. Zhurnal Vysshey shkoly ekonomiki, no 4, pp. 31-51 (in English)

DOI: $10.17323 / 2072-8166.2019 .4 .31 .51$

\section{Introduction}

The fiscal principle of tax regulation is reflected in the provisions of the legislation on taxes and levies, which define the actions of the taxpayer to fulfill the obligation to pay taxes, levies, social contributions.

The fulfillment of the tax obligation implies that the payment of taxes, levies, social contributions must be made, firstly, in full, and, secondly, on time: the obligation to pay a tax must be fulfilled within the time limit set by legislation on taxes and levies (Cl. 1 of Art. 45 of the Tax Code of the Russian Federation (hereinafter - "Tax Code").

\section{The concept of the time limits of performance of tax liability}

The time limit for tax payment is one of the mandatory elements of taxation, which is determined by the legislation on taxes and levies when setting a tax. Payment time limits as defined in Art. 57 of the Tax Code are established in relation to each tax, levy, social contribution. In case of its violation, penalties are paid in the manner and on the conditions stipulated by the Tax Code of the Russian Federation, and the amount not paid in time becomes an arrears and is subject to levy in the prescribed manner. The Tax Code (Art. 58) provides for the accrual of penalties also in case of violation of the time limits for the payment of advance payments provided for by the legislation on taxes and levies for certain taxes (income tax, transport tax, property tax of organizations, for example).

Thus, the fiscal parameters of the tax liability are not limited only to determining the amount of tax payment, but also imply the obligatory fixing of the term 
of such payment. Violation of the period for fulfillment of tax obligations obviously damages the fiscal interests of the state and local governments (mestnoe samoupravlenie). In such cases, the state, following the need for timely and full levy of legally established taxes and levies as a condition for proper financial support of the constitutional functions of public authority and exercising its fiscal sovereignty, has the right and the obligation to establish effective control mechanisms and responsibilities in the field of taxation, which, without violating constitutional rights and freedoms of man and citizen, would ensure the proper implementation by taxpayers of the tax duty imposed on them and the protection of the public interest in cases of non-payment or partial payment of the tax (the definition of the Constitutional Court on December 7, 2010 № 1572-O-O).

Failure to pay tax on time, as the Constitutional Court of the Russian Federation notes in its decisions, should be compensated by "repaying a tax and full compensation for damage suffered by the state as a result of late tax payment", and this is why the amount of tax not paid on time (arrears) is added penalty as an additional payment to compensate for the "loss of the state treasury as a result of the failure to receive tax amounts on time in case of a tax delay" (Resolution of the Constitutional Court of the Russian Federation of December 17, 1996 G. № 20-P).

The time limits for the payment of tax should be defined in the act of legislation on taxes and levies clearly, so that every taxpayer knows when he should pay a tax, levy, social contribution.

In tax law, the time limits can be determined in several ways:

a calendar date (for example, water tax is payable no later than the 20th day of the month following the expired tax period (Art. 333.14 of the Tax Code), transport tax by individuals is paid no later than December 1 of the year following the expired tax period (Art. 363 of the Tax Code),

expiration of a period of time calculated in years, quarters, months and days (for example, in the Kaluga region, the property tax of organizations is paid within ten days from the day set for the submission of a tax return for the corresponding tax period (Art. 6 of the Law of the Kaluga region of November 10, 2003 № 263OZ "On Corporate Property Tax");

an indication of an event that must occur, or an action that must be committed (for example, the corporate profit tax is paid no later than the time limit set for filing tax returns for the relevant tax period (Art. 287 of the Tax Code), the state duty for application for the issuance of documents - prior to the issuance of documents (Art. 333.18 of the Tax Code).

The special importance of terms for tax regulation explains the inclusion in Art. 8 of the Tax Code, which establishes the rules for calculating the time limits in tax law (when determining a period of time, an action can be performed during the entire period of time; an action for which a time limit is set can be completed before 24 o'clock on the last day of the time limit, etc.). 
The legislation on taxes and levies, setting time limits for the payment of taxes, levies, social contributions, while allowing for the early execution of tax duties.

\section{The taxpayer's right to alter the time periods for the payment of tax, levy, social contribution}

Ensuring parity of compliance with public and private interests in tax regulation, the legislator enshrines in the Tax Code (Art. 21) the taxpayer's right to alter the tax payment time limit in the manner prescribed by the legislation on taxes and levies.

An alteration in the time limit for the payment of tax means the transfer of the established time limit for payment, including the one that has not been incurred, to a later date. If the tax payment time limit is specified in the tax payment request sent to the taxpayer based on the results of the tax audit, then an alteration in the tax payment time limit is the postponement of the tax payment to a later date from the tax payment date indicated in the tax authority request. At the same time, the time limit for the payment of tax may be altered both with respect to the entire amount of tax payable, and to a separate part of it.

An alteration in the time limit for the payment of tax does not cancel the existing one and does not create a new duty to pay tax and levy. By realizing the right to alter the time for which the tax obligation is fulfilled, the taxpayer has the opportunity to pay tax later than the legislation on taxes and levies, and not to be held legally responsible for violating tax rules.

The taxpayer's right to alter the time limit for paying tax to maintain a balance of public and private interests in the tax sphere is compensated by his duty to pay, in established cases, the interest that compensates for the damage caused to the fiscal interests of the state and municipalities in the exercise of this right.

The general procedure for exercising the taxpayer's right to alter the tax payment time limit is determined by the Tax Code (Chapter 9) and adopted in accordance with Art. 61 of the Tax Code by the order of the Federal Tax Service of Russia of December 16, 2016 № MMB-7-8/683 “On approval of the procedure for changing the time limit for tax payment, levy, social contribution, as well as penalties and fines by the tax authorities". The norms contained in these acts are applied when changing the term of taxes, levies, social contributions ${ }^{1}$, including taxes paid in accordance with special tax regimes, as well as fines and penalties.

The procedure for alteration the time limit of taxes paid in connection with the movement of goods across the customs border of the Customs Union is established by acts of customs legislation - the EAEU Customs Code (Art. 58-60) and

${ }^{1}$ With the exception of social contributions in terms of amounts related to the formation of funds to finance a funded pension. 
Federal Law № 289-FZ of August 3, 2018 “On Customs Regulation of the Russian Federation and on amendments to certain legislative acts of the Russian Federation "(Chapter 9).

Regarding taxes and levies credited to regional and local budgets, relevant regulatory legal acts of constituent entities of the Russian Federation and municipalities may be adopted (for example, the Law of the Republic of Mordovia of May 4, 2009 "On the grounds and conditions for alteration the time limits for paying regional taxes”, the Law of Kaluga Region of September 30, 2013 № 468-OZ “On Investment Tax Credit", Decision of the Arkhangelsk City Council of July 25, 2000 "On the Procedure for Granting Deferrals and Installment Plans for Payment of Taxes and Levies, as well as Penalties credited to the city budget, tax credits, investment tax credit").

Along with the imperative method of legal regulation of relations to alteration of the time limits for the payment of tax, legislation on taxes and levies allows the use of the dispositive method. Thus, in accordance with Art. 61 of the Tax Code, when considering the application from an interested person for the granting of an alteration of the time limit for paying taxes, levies, social contributions, penalties, fines (hereinafter referred to as the interested person), a body authorized to adopt decisions has the right to offer other conditions provided by law or agreement with the interested party.

With regard to the taxpayer's right to alter the tax payment term of the Tax Code (Art. 62) restrictions are established. It cannot be implemented when a number of circumstances arise:

1) if a criminal case has been initiated against the person concerned on grounds of a crime related to violation of legislation on taxes and levies;

2) if in relation to him proceedings are being held in the case of a tax offense or in the case of an administrative offense in the field of taxes, levies, social contributions, customs (in terms of taxes payable in connection with the movement of goods across the customs border);

3) if there are reasonable grounds to believe that this person will use such alteration to conceal his money or other property subject to taxation, or that person is going to leave the Russian Federation for permanent residence;

4) if during the three years preceding the day on which this person filed an application for the alteration in the tax payment time limit, the previous positive decision of the tax authority was terminated due to a violation of the terms of the corresponding alter in the tax payment term.

The earlier decision to alter the time limit for tax payment in the event of these circumstances is subject to cancellation, of which the taxpayer must be notified in the written form within three days.

In addition, the Tax Code deprives of the right to alter the time limit for the fulfillment of tax liability in relation to the tax on the profit of organizations paid on the consolidated group of taxpayers. 
Russian legislation provides for the possibility of exercising the taxpayer's right to alter the time limit for payment of tax in three main forms: 1) deferral of tax payment, 2) instalment plan,3) investment tax credit.

In the Tax Code certain restrictions are established when choosing the form in which the realization of the taxpayer's right to alter the tax payment time limit occurs.

The use of certain forms of rescheduling may extend to the fulfillment of a tax obligation only for certain taxes. Thus, an investment tax credit can be provided only for regional and local taxes and only for one federal tax — income tax (Art. 66 of the Tax Code).

Specific forms of the alteration of the time limit for the payment of a tax may be assigned to certain grounds. For example, in case of impossibility of lump sum payment of taxes according to the results of a tax audit before the expiration of the time limit for the execution of a directional claim for payment, the taxpayer can exercise his right to alter the period only by receiving installments to pay the tax (Art. 61 of the Tax Code).

Limit amounts may also be established for which the taxpayer may alter the time limits for the fulfillment of the tax obligation. If there are certain grounds (causing damage as a result of force majeure, the seasonal nature of production, the threat of signs of bankruptcy in the case of a lump sum tax) in accordance with Art. 64 of the Tax Code, the delay or installment payment of tax is provided to the organization for an amount not exceeding the value of its net assets.

\section{Bodies authorized to make decisions on alteration the time limits for the payment of taxes, levies, social contributions}

The authority to which the decision is made to alter the time limits for the fulfillment of the tax obligation (hereinafter referred to as the authorized body) is determined depending on the type of tax on which the decision is made, as well as on the procedure for crediting taxes to the budgets of the budget system of the Russian Federation .

As a general rule, the decision to alter the time limits for the payment of federal taxes, levies, social contributions is carried out by the Federal Tax Service. The interested party applies to the Federal Tax Service of Russia through the Federal Tax Service of Russia for the subject of the Russian Federation at its location (place of residence) or through the inter-regional inspection of the Federal Tax Service of Russia for the largest taxpayers.

For regional and local taxes, decisions to alter the time limits for the fulfillment of tax obligations are taken by the tax authorities at the location (residence) of 
the interested person, in consultation with the relevant financial authorities of the constituent entities of the Russian Federation and municipal entities.

If the budget legislation of the Russian Federation provides for tax crediting to the budgets of different levels of the budget system of the Russian Federation, then decisions to alter the time limits should be agreed with the relevant financial authorities according to the scheme below (Table 1).

Table 1. Procedures for agreeing on changes in the timing of tax liability

\begin{tabular}{|c|c|c|}
\hline Type of tax & Budget the tax credited into & $\begin{array}{l}\text { Coordination of the decision } \\
\text { to change the deadline }\end{array}$ \\
\hline \multirow{3}{*}{$\begin{array}{l}\text { Federal } \\
\text { tax or levy }\end{array}$} & Federal Budget & FTS of Russia \\
\hline & Regional budgets & $\begin{array}{l}\text { FTS of Russia in coordination with } \\
\text { the financial body of the subject } \\
\text { of the Russian Federation }\end{array}$ \\
\hline & Local budgets & $\begin{array}{l}\text { FTS of Russia in coordination with } \\
\text { the financial body of the municipality }\end{array}$ \\
\hline \multirow[t]{2}{*}{ Regional tax } & Regional budgets & $\begin{array}{l}\text { Tax authority at the location (residence) } \\
\text { of the interested person in coordination } \\
\text { with the financial authority of the constitu- } \\
\text { ent entity of the Russian Federation }\end{array}$ \\
\hline & Local budgets & $\begin{array}{l}\text { Tax authority at the location (residence) } \\
\text { of the interested person in coordination } \\
\text { with the financial body of the municipality }\end{array}$ \\
\hline
\end{tabular}

In addition, the Tax Code (Art. 63) establishes special rules for alteration of the time limit for paying a number of federal and regional taxes.

With regard to federal taxes and levies, special rules apply to taxes paid as part of customs duties, state duties, and in some cases when deciding to alter the time limit for income tax and personal income tax.

On federal taxes payable in connection with the movement of goods across the customs border of the Customs Union, the decision to alter the payment time limits are taken by the Federal Customs Service or its authorized customs authorities (Art. 63 of the Tax Code, Art. 52 of the Federal Law of August 3, 2018 № 289 -FZ "On Customs Regulation in the Russian Federation and on Amendments to Certain Legislative Acts of the Russian Federation").

The decision to alter the time limit for paying the state levy is taken by the body authorized to perform legally significant actions for which the state levy is payable (Chapter 25.3 of the Tax Code).

\footnotetext{
${ }^{2}$ Except the state duty.
} 
As regards the tax on profit of organizations at the tax rate established for crediting this tax to the budgets of the constituent entities of the Russian Federation, the decision to alter the period for which the tax obligation is fulfilled is made by the body authorized by the legislation of the constituent entities of the Russian Federation. Respective powers are granted, as a rule, to a regional government (for example, the Novgorod region) or a financial body of a constituent entity of the Russian Federation (a regional finance ministry in the Stavropol Region, Sakhalin Region, etc.). Other options are possible (for example, in the Saratov region, the law gives such powers to the "executive body of the region authorized in the field of investment policy"). In some constituent entities of the Russian Federation, legislation gives the regional financial institution the right to decide on alteration of the time limit for paying income tax, and the authority to determine the procedure for making such a decision is credited to the regional government (for example, the Nizhny Novgorod region).

For personal income tax, a special rule for determining the authorized body is established for the tax payable by individuals who are not individual entrepreneurs, in terms of income, upon receipt of which the tax is not withheld by tax agents. In this case, the decision to alter the time limit for the payment of tax is taken by the tax authorities at the place of residence of such persons. At the same time, decisions to alter the time limits for the payment of tax on these incomes in terms of the amounts to be credited to regional and local budgets must be agreed with the financial authorities of the respective constituent entities of the Russian Federation and municipal entities.

Regarding regional taxes, special rules for the establishment of an authorized body are applied when making decisions on alteration of the time limits of tax payments in the form of an investment tax credit. In this case, the decision is made by the authority, which is established in the relevant legislation of the subject of the Russian Federation. As noted above, at the level of the subject of the Russian Federation, such powers are usually vested in the regional government or regional financial body.

Not being empowered by the Tax Code to decide on alterations in tax payment terms, the courts, in accordance with the Arbitration Procedure Code of the Russian Federation (Art. 324) and the Civil Procedure Code of the Russian Federation (Art. 203), in the presence of circumstances that impede the execution of a judicial act, has the right to postpone or defer the execution of a judicial act, including the recovery of arrears from the taxpayer.

Judicial practice notes that when deciding whether to delay or deferring a court decision on tax or levy, the court does not consider the issue of postponing the tax payment, but implements the powers granted to it by procedural legislation to grant a postponement or installment plan for the execution of a judicial act (the FAS decision March 6, 2009 in case № A44-265 / 2008). At the same time, the 
courts are not obliged to coordinate their decisions with the tax authorities and take into account the provisions of the Tax Code on alteration of the tax time limit (FAS resolution of the Volgo-Vyatsky district of April 26, 2007 in case № A4336540 / 2005-40-468).

\section{Deferral and installment plan of payment of tax, levies, social contributions}

The most commonly used in practice forms of exercising the taxpayer's right to alter the tax payment time limit (levy, social contributions) are deferral and installment plan.

A deferment is an alteration of the time limit for paying the tax with a lump sum payment of the debt (deferred amount). The installment plan involves an alteration of the time limit for the payment of tax with the phased payment of the amount of the debt (installment payment) in accordance with the debt repayment schedule.

As a general rule, deferment and installments are provided for a period not exceeding one year. From 2017 on the payment of federal taxes (only in the part credited to the federal budget) and insurance contributions the Tax Code provides for the possibility of extending the deferral or installment plan for a period of more than one year, but not more than three years.

A deferral or instalment plan for the payment of tax may be granted to an interested person whose financial position does not enable that tax to be paid within the established time limit but there are sufficient grounds to believe that the person concerned will be able to pay that tax within the period for which the deferral or instalment plan is granted. A mandatory condition for granting a deferral or installment plan must be present as one of the grounds specified in the Tax Code (Art. 64):

causing damage to an interested party as a result of a natural calamity, an industrial disaster or other circumstances of insurmountable force;

cases of delayed financing from the budget ${ }^{3}$;

there is a risk that indications of insolvency (bankruptcy) would arise for the interested person if that person were to pay tax as a lump sum;

property status of an individual excludes the possibility of a lump sum tax payment;

3 This refers to cases of failure to provide or untimely provision of budget allocations, limits of budgetary obligations to the interested person, as well as cases of failure or untimely bringing the maximum amount of financing expenses to the interested party - the recipient of budgetary funds, as well as facts of non-transfer or untimely transfer to the interested person from the budget in the amount sufficient for the timely execution of the obligation to pay tax, cash, including on account of payments of services rendered (works performed, goods supplied) for state and municipal needs. 
production or sale of goods, works or services by the interested person is seasonal in nature;

impossibility of lump sum payment of taxes payable on the basis of the results of a tax audit, before the expiration of the period for fulfillment of the claim for payment $t^{4}$.

If there are listed grounds (except in cases of delayed financing from the budget), a deferral or installment plan on tax payment may be provided to the organization for an amount not exceeding the value of its net assets.

For taxes credited to regional and local budgets, constituent entities of the Russian Federation and municipalities, within the framework of their competence, may establish additional grounds for deciding whether to grant the deferral or installment plan for the payment of such taxes. Thus, in accordance with the Law of the Republic of Komi on March 1, 2016 № 15-RZ “On Establishing Additional Grounds and Other Conditions for Deferring or Installing Payment for Regional Taxes, Penalties and Fines", an additional reason for granting deferral or installment plans for paying regional taxes, penalties and fines are the implementation by an interested person of one of the types of economic activity listed in the Law (forestry and logging, mining of coal, etc.) in the territory of a single-industry municipality (monotowns).

Interest is charged on the amount of debt arising from the deferral or installment plan for tax payment at a rate equal to one second of the refinancing rate of the Central Bank of the Russian Federation, which was valid for the period of deferral or installment plan. When granting a deferral or an installment plan due to damage caused as a result of force majeure circumstances or in case of a delay in financing from the budget, the interested person is exempt from paying interest.

The interest payment is intended to ensure the observance of the fiscal interests of the territorial public-legal entities, in whose income the corresponding tax revenues are to be credited.

The fiscal interests of public law education in the provision of deferral and installment payments of tax payments are provided in the forms provided by the Tax Code of the Russian Federation - pledge, surety and bank guarantee.

\section{The procedure for granting a deferral or installment plan}

The application for granting a deferral or installment plan for tax payment is submitted to the body authorized to make the relevant decision. In it, the interested person, among other things, undertakes to pay the interest charged on the amount owed.

\footnotetext{
${ }^{4}$ With this basis, the interested party can be provided only installments.
} 
Attached to the application:

documents on the financial status of the interested person (certificates of banks ${ }^{5}$, list of counterparties - debtors of this person, indicating the prices of contracts concluded with relevant counterparties);

documents confirming the existence of grounds for alteration of the tax payment time limit;

the obligation of the interested person.

The obligation of the interested person is a document drawn up in the prescribed form (Appendix 2 to the Procedure approved by order of the Federal Tax Service of Russia on December 16, 2016 № MMB-7-8/683@), in which the interested person undertakes to comply with the conditions under which the decision to grant a deferral or installment plan is taken, as well as the schedule of debt repayment:

to pay taxes in full and in a timely manner (levies, social contributions, penalties, fines);

at the time of payment of the amounts of deferred (installment) debt, debt on an investment tax credit, pay the amounts due promptly and in full;

in case of occurrence of grounds excluding an alteration in the time limit for tax payment, immediately notify the authorized body that provided the deferral (installment plan, investment tax credit), and the tax authority at the place of registration.

As documents confirming the existence of grounds for alteration of the time limit for tax payment, the following may be submitted:

a conclusion on the occurrence of force majeure circumstances and an act of the competent authority in which the damage caused to the person concerned as a result of the specified circumstances is assessed;

a document of a financial body or the main manager (manager) of budgetary funds, confirming the fact of a delay in financing from the budget;

document of the state (municipal) customer, containing information about the amount of money that was not transferred to the interested party in payment for services rendered by such person, work performed, goods supplied for state (municipal) needs;

information on movable and immovable property of a physical person, with the exception of property that cannot be recovered in accordance with the legislation of the Russian Federation;

document confirming that in the total income from the sale of goods, works, services of the interested person, the share of its income from industries and ac-

${ }^{5}$ Certificates on the monthly turnover of cash and precious metals on the accounts of this person in banks (for each month from the six months preceding the filing of the said application), on the availability of his settlement documents, placed in a card file of unpaid settlement documents, on cash balances and precious metals on all that person's bank accounts. 
tivities included in the list of industries and activities that are seasonal in nature is at least 50 percent $^{6}$.

Documentary evidence of the existence of certain grounds is not provided, and the authorized bodies independently carry out a check of their presence. For example, the existence of a risk of insolvency (bankruptcy) of an interested person in the case of a lump sum tax payment is confirmed by the analysis of the financial condition of an economic entity conducted by the FTS of Russia in accordance with the methodology approved by the Ministry of Economic Development of Russia (Order № 175 of the Ministry of Economic Development of April 18, 2011). On approval of the methodology for analyzing the financial condition of the interested person in order to establish the threat of occurrence of signs of his bankruptcy in case of a lump sum payment of tax by the person").

The impossibility of lump sum payment of taxes payable as a result of a tax audit, before the expiration of the period for fulfilling the demand for payment, shall be established by the authorized body in accordance with the criteria specified in paragraph 5.1 of the Art. 64 of the Tax Code.

The decision to alter the tax payment time limit is carried out by the authorized body within 30 working days from the date of receipt of the application of the interested person.

At the request of the interested person, the authorized body has the right to decide on a temporary - for the period of consideration of the application for granting a deferral or installment plan - the suspension of the payment of the debt amount.

The decision of the authorized body on granting a deferral (installment plan) of tax payment shall contain information on:

an interested person to identify it;

the applicable form of alteration of the time limit for the payment of tax;

types and amounts of mandatory payments for which the decision was made;

The time of the deferral or installment plan and the debt repayment schedule.

The decision specifies the conditions for granting a deferral or installment plan: specifies the amount of interest for using the deferral (installment plan), determines the specific form of ensuring the fulfillment of the tax obligation, formulates the obligation to timely and full payment during the validity period of the deferment (installment plan) fine).

It also indicates the reasons for the cancellation of the decision to alter the time limit for tax payment:

termination of grounds on which a deferral (installment plan) was granted;

${ }^{6}$ Such a document is drawn up by the interested person himself, and for his preparation is used the Government Decree of April 6, 1999 № 382 “On the lists of seasonal industries and activities used for tax purposes". 
non-compliance by the interested party with the terms and conditions of repayment of the deferral (installment plan);

failure to fulfill their obligations.

The decision on granting a deferral (installment plan) comes into effect from the date established in this decision. At the same time, if the delay (installment plan) is provided on the security of property, then the decision on its provision comes into effect only after the conclusion of the pledge of property agreement.

Penalties due for the entire time from the day set for tax payment until the day when the decision on deferment (installment plan) comes into force are included in the amount of debt if the specified payment period precedes the day this decision enters into force.

The decision on refusal to provide a deferment or installment plan for tax payment must be motivated and contain the reason for the refusal (for example, the absence of the required document in the file submitted by the interested person). The decision to refuse may be appealed by the interested party in the manner established by the legislation of the Russian Federation.

In the event that the interested party submits false information or reveals circumstances that preclude the possibility of alteration the tax time limit, the decision to grand deferral or installment plan is canceled.

\section{Alterations in the timing of tax payments as part of customs payments}

Customs legislation, as already noted, establishes special rules for the payment of taxes on goods moved across the customs border of the Customs Union.

In accordance with the EAEU Customs Code (Art. 58), the timing of tax payments as part of customs payments is altered exclusively in the form of a deferral or installment plan. At the same time, there are grounds for alteration the time limits for paying taxes, the conditions, the procedure for alteration them, etc. established by the legislation of the EAEU Member State in which they are paid (in the Russian Federation Art. 49-52 of the Federal Law "On Customs Regulation in the Russian Federation and on Amendments to Certain Legislative Acts of the Russian Federation").

Deferral or installment plan for the payment of taxes is granted for a period of one to six months in respect of goods placed under the customs procedure of release for domestic consumption, and subject to the enforcement of the obligation to pay taxes.

The tax time limit can be altered only if there are grounds established by law causing damage to the payer as a result of force majeure circumstances, delaying him of financing from the federal budget or paying for the state order made by him, making deliveries under an international agreement, etc. 
At the same time, a number of circumstances exclude the possibility of granting the right to a deferral or installment plan to an interested person:

lack of duly executed documents confirming the existence of a basis for an alteration of the time limit for tax payment;

the obligation to pay the customs duties, taxes, special, anti-dumping, countervailing duties, interest and penalties not fulfilled within the prescribed period;

initiation of bankruptcy proceedings against the interested person;

the presence of two or more facts of bringing the interested person to administrative responsibility for offenses in the field of customs (within one year before applying for a granting of deferral or installment plan);

initiation of a criminal case against the founders, heads of the interested person, the preliminary investigation of which falls within the competence of the customs authorities;

non-submission of documents to ensure the fulfillment of tax obligations, etc.

The right for defferal or installment on the payment of taxes in the customs legislation is due to the customs procedure chosen by the taxpayer. Deferral or installment payment of taxes may be granted only with regard to goods placed under the customs procedure of release for domestic consumption. At the same time, the use of the customs procedure of release for domestic consumption is not always guaranteed to provide a deferment or installment plan for the payment of VAT and excise taxes on imported goods. If foreign economic activity participant releases goods prior to the submission of a customs declaration ${ }^{7}$ in connection with the performance of customs operations as a priority, he or she cannot exercise the right to pay taxes with the deferral or installments.

The decision to grand the deferral or installment plan for the payment of taxes is taken by the customs authority within a period not exceeding 10 working days from the date of filing of the relevant application. Such a decision specifies the period for which the deferral or installment plan is granted, and in installments it is approved a phased payment schedule.

\section{Investment tax credit}

Another form of realization of the taxpayer's right to alter the tax time limit, along with deferral and installment plan, is an investment tax credit, which can be used by the taxpayer organization to extend the time limit for paying regional

7 This possibility is provided in Article 120 of the EAEU Customs Code, for example, for goods imported as part of investment projects, as well as goods necessary for disaster relief, military products, goods that are subject to rapid deterioration, as well as for animals, international postal express shipments, humanitarian and technical assistance, etc. The list of such goods can be expanded by the Eurasian Economic Commission. 
and local taxes (corporate property tax, transport tax, land tax) and one federal tax - income tax.

An investment tax credit is an alteration of the tax payment time limit, in which an organization is given the opportunity to reduce its tax payments within a certain period and within certain limits, followed by a phased payment of the loan amount and accrued interest.

It can be granted for a period of one to five years. For organizations included in the register of residents of the territorial development zone, the period may be extended to 10 years.

Relations on investment tax credits are executed in the relevant agreement. The organization that has entered into such an agreement has the right to reduce its payments on the relevant tax during the term of the investment tax credit agreement. The Tax Code (Art. 66) establishes an investment tax credit mechanism a reduction shall be made in respect of each payment of the relevant tax for which investment tax credit was granted for each reporting period until such time as the amount remaining unpaid by the organization as a result of such reductions (the accumulated amount of credit) becomes equal to the amount of credit provided for by the relevant agreement. The specific procedure for reducing tax payments is determined directly by the investment tax credit agreement.

A taxpayer organization may conclude more than one investment tax credit agreement, which has not expired by the time of the next tax payment. In this case, the accumulated loan amount is determined separately for each of these contracts. The increase in the cumulative loan amount is made at the beginning in relation to the first term of the contract. Upon reaching this accumulated loan amount stipulated by the contract amount, the organization can increase the accumulated loan amount already under the following contract.

The Tax Code establishes quantitative restrictions on payments under the investment tax credit agreement.

First, the maximum amount by which tax payments can be reduced, regardless of the number of investment tax credit agreements concluded, cannot exceed 50\% of the tax amount that an organization should pay according to the general rules (i.e. excluding the existence of the investment tax credit agreements).

Secondly, the loan amount accumulated during the tax period cannot exceed $50 \%$ of the tax amount due for this tax period.

Allowed to transfer the loan amount for the following reporting periods. So, if the accumulated loan amount exceeds the limits of tax reduction for such a reporting period, then the difference between this amount and the maximum allowable amount is transferred to the next reporting period. It is also transferred to the next tax period and is recognized as the cumulative loan amount in the first reporting period of the new tax period overly accumulated for the tax period, the loan amount received from an organization that had losses as a result of individual reporting periods during the tax period or losses for the entire tax period. 
The name of the tax credit itself - investment - describes the grounds for providing this form of the alteration of the time limit for the tax payment. In accordance with the Tax Code (Art. 67), it is provided to organizations with connections to the implementation of investment or other economic activities relevant to the state or a municipality. The type of economic activity for which the organization acquires the right to alter the tax payment time limit is linked to the size of the tax credit provided (Table 2).

Table 2. Investment tax credit

\begin{tabular}{|c|c|c|}
\hline $\begin{array}{l}\text { Basis for an investment } \\
\text { tax credit }\end{array}$ & $\begin{array}{c}\text { Investment } \\
\text { tax loan amount }\end{array}$ & $\begin{array}{l}\text { Documents confirming } \\
\text { the right to receive } \\
\text { an investment tax credit }\end{array}$ \\
\hline $\begin{array}{l}\text { 1) conducting R\&D work or } \\
\text { technical modernization of } \\
\text { its own production activ- } \\
\text { ity, including with the aim } \\
\text { of creating jobs for disabled } \\
\text { persons, or carrying out a } \\
\text { measure or measures for the } \\
\text { reduction of adverse environ- } \\
\text { mental impact, raising the } \\
\text { energy efficiency } \\
\text { of the production of goods, } \\
\text { performance of work and } \\
\text { rendering of services, etc. }\end{array}$ & $\begin{array}{l}100 \% \text { of the cost of } \\
\text { the purchased equipment } \\
\text { used exclusively for this } \\
\text { type of activity }\end{array}$ & $\begin{array}{l}\text { a) documents confirming } \mathrm{R} \& \mathrm{D} \\
\text { and technical re-equipment of } \\
\text { production; } \\
\text { b) documents confirming } \\
\text { the fact of acquisition } \\
\text { and the cost of the equipment } \\
\text { acquired by the organization } \\
\text { used for these purposes; } \\
\text { c) the business plan of } \\
\text { the investment project }\end{array}$ \\
\hline $\begin{array}{l}\text { 2) carrying out technical ad- } \\
\text { aptation or innovation work, } \\
\text { including the creation of new } \\
\text { or improvement of existing } \\
\text { technologies and the creation } \\
\text { of new types of raw materials } \\
\text { and other materials, etc. }\end{array}$ & $\begin{array}{l}\text { determined by } \\
\text { the agreement between } \\
\text { the authorized body } \\
\text { and the taxpayer organiza- } \\
\text { tion }\end{array}$ & $\begin{array}{l}\text { a) documents confirming } \\
\text { the implementation of innova- } \\
\text { tive activities; } \\
\text { b) the business plan of } \\
\text { the investment project }\end{array}$ \\
\hline $\begin{array}{l}\text { 3) executing an order which } \\
\text { is highly important for the } \\
\text { social and economic de- } \\
\text { velopment of the region or } \\
\text { provides essential services to } \\
\text { the public }\end{array}$ & $\begin{array}{l}\text { determined by } \\
\text { the agreement between } \\
\text { the authorized body } \\
\text { and the taxpayer organiza- } \\
\text { tion }\end{array}$ & $\begin{array}{l}\text { a) documents confirming } \\
\text { the existence of the said } \\
\text { grounds; } \\
\text { b) a certificate on the imple- } \\
\text { mentation of the order or } \\
\text { the provision of services issued } \\
\text { by the authorized body of } \\
\text { the constituent entity of the } \\
\text { Russian Federation }\end{array}$ \\
\hline $\begin{array}{l}\text { 4) fulfilling the State defense } \\
\text { order }\end{array}$ & $\begin{array}{l}\text { determined by the agree- } \\
\text { ment between } \\
\text { the authorized body and } \\
\text { the taxpayer organization }\end{array}$ & $\begin{array}{l}\text { a) documents confirming } \\
\text { the existence of the said grounds; } \\
\text { b) certificate of fulfillment } \\
\text { of the State defense order }\end{array}$ \\
\hline
\end{tabular}




\begin{tabular}{|l|l|l|}
\hline \multicolumn{1}{|c|}{$\begin{array}{c}\text { Basis for an investment } \\
\text { tax credit }\end{array}$} & \multicolumn{1}{|c|}{$\begin{array}{c}\text { Investment } \\
\text { tax loan amount }\end{array}$} & $\begin{array}{c}\text { Documents confirming } \\
\text { the right to receive } \\
\text { an investment tax credit }\end{array}$ \\
\hline $\begin{array}{l}\text { 5) investing in the creation of } \\
\text { facilities which have the high- } \\
\text { est energy efficiency rating }\end{array}$ & $\begin{array}{l}100 \% \text { of the cost of } \\
\text { the purchased equipment } \\
\text { used exclusively for this } \\
\text { type of activity }\end{array}$ & $\begin{array}{l}\text { a) documents confirming } \\
\text { the existence of the said } \\
\text { grounds; } \\
\text { b) the business plan of } \\
\text { the investment project }\end{array}$ \\
\hline $\begin{array}{l}\text { 6) inclusion in the register of } \\
\text { residents of an area develop- } \\
\text { ment zone }\end{array}$ & $\begin{array}{l}\text { no more than } 100 \% \text { of the } \\
\text { cost of capital investments } \\
\text { in the acquisition (creation, } \\
\text { reconstruction, modern- } \\
\text { ization, etc.) of depreciable } \\
\text { property used for resident } \\
\text { investment projects }\end{array}$ & $\begin{array}{l}\text { a) documents confirming } \\
\text { the existence of the said } \\
\text { grounds; } \\
\text { b) the business plan of } \\
\text { the investment project }\end{array}$ \\
\hline \multicolumn{2}{|l}{} \\
\hline
\end{tabular}

\section{Investment tax credit agreement}

Investment tax credit is provided on the basis of filing an application by an interested organization, in which it undertakes an obligation to pay interest accrued on the amount of debt. The application is accompanied by the package of documents confirming that the organization has the right to receive an investment tax credit (see diagram 2). The decision on granting an investment tax credit is carried out by the authorized body in agreement with the financial authorities within 30 days from the date of receipt of the application.

Arising relations are formalized by an agreement between the organization and the authorized body, the form of which is established by the authorized body (for example, the order of the Federal Tax Service of Russia of 11/29/2005 №SAE-3-19/622@ "On approval of investment tax credit forms", Order of the Ministry of Economy of Omsk Region dated July 5, 2013 "On approval of the form of an investment tax credit agreement"). At the same time, the presence of one or several investment tax credit agreements with an organization cannot serve as an obstacle to concluding another investment tax credit agreements with this organization for other reasons.

The investment tax credit agreement must contain the following information:

loan amount indicating the tax on which the investment tax credit was provided;

the procedure for reducing payments on the relevant tax;

contract time;

interest accrued on the loan amount;

the procedure for repayment of the loan amount in a period not exceeding the period for which an investment tax credit is granted in accordance with the contract; 
the procedure and maturity of accrued interest;

an indication of the method of securing liabilities (if an investment tax credit is provided on the security of property, an agreement on the pledge of property is concluded);

responsibility of the parties.

The contract includes provisions according to which, during the term of the contract, as a rule, the sale or transfer of possession, use or disposal of equipment or other property to other persons, the acquisition of which was a ground for granting an investment tax credit, is not allowed ${ }^{8}$.

The interest accrued on the loan amount is determined in the contract subject to the restrictions established by the legislation on taxes and levies. Thus, the Tax Code establishes the limits for calculating interest on the loan amount - at least $1 / 2$ and not more than $3 / 4$ of the refinancing rate of the Central Bank of the Russian Federation. At the same time, no interest is accurred on the tax credit granted to a resident of the territorial development zone (Art. 67 of the Tax Code).

\section{Regional and municipal features of the legal regulation of investment tax credit}

The laws of the constituent entities of the Russian Federation (on regional taxes and on corporate income tax in the part that is to be credited to the regional budget) and regulatory legal acts of representative bodies of municipal formations (on local taxes) may establish other grounds and conditions for granting an investment tax credit - the duration of the investment tax credit, interest rates on the loan amount, etc. For example, the Law of the Stavropol Region ${ }^{9}$ as an additional basis. A provision of investment tax credit determined by the inclusion of the organization in the register of residents of the Municipal Development Zone, and the decision of the City Duma of the city of Yuzhno-Sakhalinsk on May 27, $2015^{10}-$ implementation of investment projects included in the list of priority investment projects of the urban district, which is approved by the city administration.

The regional and municipal acts may set limits on the amount of investment tax credits, the terms and the rate at which interest is calculated. In the Kirov Region ${ }^{11}$, for example, the total amount of an investment tax credit cannot exceed $70 \%$ of the

${ }^{8}$ If the contract provides for the possibility of the sale (transfer) of such property, then the conditions of such sale (transfer) should be determined.

9 The law of the Stavropol Region of November 28, 2006 № 83-kz “On investment tax credit”.

${ }_{10}$ The decision of the City Duma of the city of Yuzhno-Sakhalinsk of 05.27.2015 № 155 / 11-15-5 "On the establishment of an additional basis and conditions for granting an investment tax credit in the territory of the urban district" City of Yuzhno-Sakhalinsk".

${ }^{11}$ Law of the Kirov region of May 4, 2007 № 122-ZO “On other grounds and conditions for granting an investment tax credit in the Kirov region". 
value of an investment project. In accordance with the legislation of the Amur Region $^{12}$, an investment tax credit for additional reasons may be granted for a payback period of an investment project, but not more than five years from the day when the decision to grant it is made with interest charged based on the rate equal to $1 / 3$ of the refinancing rate Central Bank of the Russian Federation, in effect on the day interest.

Regional legislation may establish a pre-emptive right to receive an investment tax credit. Thus, in Kabardino-Balkaria Republic ${ }^{13}$, organizations with investment projects that provide for this priority right are given to:

the shortest period of return of funds received;

the largest number of newly created jobs per one ruble of investment tax credit provided;

the largest amount of tax revenues to the regional consolidated budget from the project implementation per one ruble of the investment tax credit provided.

\section{Termination of legal relations of alteration of the time limit for tax payment}

Deferral, installment plan or investment tax credit are terminated, as a general rule, after the expiration of the relevant decision or agreement.

Early termination of legal relations to alter the time limit for the payment of tax arises in the case of payment of the due amount of tax, levies, social contributions and the corresponding interest before the expiration of the established period.

Early termination of such legal relations may be caused by violations by the taxpayer of the rules in accordance with which he received the right to alter the time limit for tax payment.

If the interested party violates the conditions for granting a deferral or installment plan, its action may be terminated early by the decision of the authorized body that made the decision on a corresponding alteration in the period for which the tax obligation was fulfilled.

In this case, the taxpayer must, within one month after receiving the relevant decision, pay:

the difference between the amount of debt determined in the decision on granting a deferral (installment plan), increased by the amount of interest, and actually paid amounts and interest (unpaid amount of debt);

penalties that are calculated for each calendar day, starting from the day following the day of receiving this decision, until the day of payment of this amount inclusive.

12 The law of the Amur region of May 13, 2009 № 201-OZ “On the establishment of additional grounds and other conditions for granting deferral or installment plans for the payment of regional taxes, penalties and fines and other grounds and conditions for granting an investment tax credit".

${ }^{13}$ Law of the Kabardino-Balkarian Republic of March 22, 2002 № 18-RZ “On Investment Tax Credit”. 
Investment tax credit agreement may be terminated early by agreement of the parties or by court decision.

If the basis for termination of the contract is a violation of its essential conditions by the taxpayer, then the violator is obligated to restore the state's fiscal interests (Table 3).

Table 3. Protection of the fiscal interests of the state in case of early termination of the investment tax credit agreement

\begin{tabular}{|l|l|l|}
\hline \multicolumn{1}{|c|}{ Grounds for termination } & $\begin{array}{l}\text { Measures to protect the fiscal interests } \\
\text { of the state }\end{array}$ & $\begin{array}{c}\text { Terms } \\
\text { of implementation } \\
\text { of these measures }\end{array}$ \\
\hline $\begin{array}{l}\text { violation of the conditions } \\
\text { for the sale or transfer } \\
\text { to the possession, use or dis- } \\
\text { posal of equipment or other } \\
\text { property to other persons, } \\
\text { the acquisition of which was } \\
\text { the basis for granting an } \\
\text { investment tax credit }\end{array}$ & $\begin{array}{l}\text { payment of all unpaid amounts, } \\
\text { as well as the corresponding penalties and } \\
\text { the agreement at the refinancing rate of } \\
\text { the Central Bank of the Russian Federa- } \\
\text { tion, which was in force from the conclu- } \\
\text { sion to the termination of the specified } \\
\text { agreement }\end{array}$ & $\begin{array}{l}\text { within one month } \\
\text { from the date } \\
\text { of termination } \\
\text { of the contract }\end{array}$ \\
\hline $\begin{array}{l}\text { violation of the obligations, } \\
\text { in connection with the execu- } \\
\text { tion of which an investment } \\
\text { tax credit was received by } \\
\text { an organization that fulfills } \\
\text { a particularly important } \\
\text { order for the socio-economic } \\
\text { development of the region } \\
\text { or provides especially impor- } \\
\text { tant services to the public }\end{array}$ & $\begin{array}{l}\text { payment of the entire amount of unpaid } \\
\text { tax and interest on this amount accrued } \\
\text { for each calendar day of the contract at } \\
\text { the refinancing rate of the Central Bank } \\
\text { of the Russian Federation }\end{array}$ & $\begin{array}{l}\text { within the period } \\
\text { specified by the } \\
\text { lontract, but no }\end{array}$ \\
\hline $\begin{array}{l}\text { violation of the obligations by three } \\
\text { an organization included in } \\
\text { the register of residents of a } \\
\text { territorial development zone } \\
\text { months from the } \\
\text { date of termination } \\
\text { of the contract }\end{array}$ & $\begin{array}{l}\text { payment of the entire amount of un- } \\
\text { paid tax and interest on this amount, } \\
\text { accrued at the refinancing rate of the } \\
\text { Central Bank of the Russian Federation } \\
\text { for each calendar day, starting from } \\
\text { the day following the day of termina- } \\
\text { tion of the contract, until the day of tax } \\
\text { payment }\end{array}$ & $\begin{array}{l}\text { mo later than three } \\
\text { the date of termi- } \\
\text { nation of the in- } \\
\text { agreement tax credit }\end{array}$ \\
\hline
\end{tabular}

\section{O-4 国 References}

Cartou L. (1981) Droit fiscal international et européen. Paris: Dalloz, 280 p.

Cuadrado Ramos J. (2018). Principios de Derecho Fiscal. Madrid: Ra-Ma, 134 p.

Demin A.V. (2010) General theory of tax norms. Moscow: INFRA-M, 266 p. (in Russian) 
Grosclaude J., Marchessou P. (2007) Droit fiscal général. Paris: Dalloz, 608 p.

Karaseva M.V. (ed.) (2009) Tax law of the Eastern European countries: general part. Moscow: Wolters Kluver, 336 p. (in Russian)

Ovsyannikov S.V. (2009) Forms and limits of interaction between tax law and civil law. Vestnik VAS RF, no 1, pp. 83-100 (in Russian)

Porohov E.V. (2009) Theory and practice of Kazakhstan tax law: main issues. Almaty: Nalogovy ekspert, 456 p. (in Russian).

Ryabov A.A. (2014) The influence of civil law on tax relations: doctrine, interpretation, practice. Moscow: NORMA, 224 p. (in Russian)

Sadikov O.N. (2011) Civil law conceptions in public law. Zhurnal rossiyskogo prava, no 9, pp. 19-28 (n Russian)

Smolitskaya E.E. (2018) Civil law institutes, terms and notions in the tax law. Moscow: Prospect, 176 p. (in Russian)

Terra B., Wattel P. (2012) European Tax Law. 6th ed. The Hague: Kluwer Law International, $634 \mathrm{p}$.

Thuronyi V. (2003) Comparative Tax Law. Deventer: Kluwer Law International, 373 p.

Heckly C. (2006) Fiscalité et mondialisation. Paris: LGDJ, 154 p.

Volkova N.N. (2010) Reception of civil law norms in tax legislation. Moscow: Yurlitinform, 160 p. (in Russian)

Yakovlev V.F. (2006) Civil legal method of the regulation of social relations. Moscow: Statut, 240 p. (in Russian) 